\title{
From molecules to mind
}

\section{Eisenberg'}

SUMMARY This paper describes the relation between genes at the molecular level and the brain at the organ level, and biological, social and environmental factors. The malleability of the brain and the effect of extemal factors and experience on influencing gene expression and brain structure and function are discussed.

\section{Introduction}

Two and a half millennia ago, the Hippocratic author of the monograph $O n$ the $s a-$ cred disease (written to prove epilepsy was not "sacred" but natural) asserted:

Men ought to know that from the brain and the brain alone arise our pleasures, joys, laughter and jests, as well as our sorrows, pains, griefs, and tears. Through it ... we think, we see, we hear, and we distinguish the ugly from the beautiful, the bad from the good, the pleasant from the unpleasant. By the same organ, we become mad or delirious, and fears and terrors assail us ... and dreams and untimely wanderings ... All these things we endure from the brain when it is not healthy, but it becomes abnormally hot, cold, moist, or dry, or suffers any other unnatural affection.

When that paragraph was written, it was a testimony of faith; today, scientific evidence strongly supports its assertions. The brain is the organ of the mind. But our current understanding includes the recognition that the very structure of the brain is moulded by inputs from the biological and social environments to which the individual is exposed.

\section{The influence of structure on function}

At the molecular level, we now know that genetically-coded triplet codon repeats underlie the pathology of Huntington disease, Canavan disease and fragile $\mathrm{X}$ syndrome. The psychopathology of phenylketonuria results from a genetic error interrupting the production of phenylalanine hydroxylase. Yet this entirely genetic disease can be prevented by an environmental intervention, a low phenylalanine diet.

Gene effects reflect the environment they encounter. Genes and environments are multiplicative rather than additive. Attempts to separate out differential contributions are a waste of time. As the late Donald Hebb put it, "To ask how much of the phenotype is due to nature and how much to nurture is as useful as asking how much of the area of a rectangle is due to its length and how much to its height."

Nature and nurture stand in reciprocity, not opposition. What children inherit is not only their parents' genes but their parents, their peers, and the places they inhabit. Neighbourhood and neighbours matter along with parents and siblings [I]. The intellectual, social and physical characteristics of human populations reflect where people live, what they eat, the work they

'Presley Professor of Social Medicine and Professor of Psychiatry, Emeritus, Department of Social Medicine, Harvard Medical School, Boston, Massachusetts, United States of America.

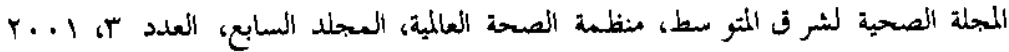


do, the air and water they take in, their interconnectedness with others, and the status they occupy in the social order as well as what they inherit: their relative vulnerabilities and resistances to environmental influences [2].

\section{The malleable brain}

A decade of imaginative research has taught us very much more about both brain and mind; the problem that continues to bedevil us conceptually is how to integrate the two domains into "brain/mindedness" [3].

Data are overthrowing dogma on all sides. We no longer think of the brain as a hardwired telephone switchboard arising from a blueprint in the genome. Formation of the ocular alternation layers in geniculate and cortex illustrates the process. Early in embryogenesis, axons from both eyes $\mathrm{mi}$ grate to, and intermingle in, the geniculate nuclei. The segregation of separate layers results from bursts of electrical activity arising in unstable retinal ganglion cells. Neither the genes governing the retma nor the genes governing the geniculate specify the ocular alternation layers; they result from an interaction between neurons in the course of development. At the next relay, the precise targeting of projections from lateral geniculate to occipital cortex in turn depends on geniculate activity. Abolishing geniculate action potentials leads axons to project to cortical areas they ordinarily bypass and many fewer thus project to the striate cortex [4]. Finally, postnatal stimulation is required for the formation of ocular dominance columns in the occipital cortex [5]. Both eyes of the newborn must receive precisely focused stimulation from the visual environment during the early months of postnatal life in order to produce a fine-tuned cortical structure.
Experience moulds the brain in a process that continues throughout life. Finger representation in the cortex is larger on the right in professional violinists and greater than it is in the rest of us [6]. It is enlarged in Braille readers [7] and it shrinks after deafferentation [8]. Brain function and structure are constantly in flux. Neurogenesis continues through life in the adult brain [9].

Effective psychotherapy changes brain function. Obsessive-compulsive disorder is associated with changes in the basal ganglia made visible by imaging techniques. Obsessive-compulsive disorder symptoms are reduced by cognitive behaviour therapy or by serotonin-reuptake inhibitors. What happens to brain abnormalities? Whether treatment gains are produced by drug or psychotherapy, there is a relative "normalization" of brain change [10]. Brain imaging techniques reveal linkages between. mind and brain never imagined a decade ago.

\section{Maternal care influences gene expression}

Francis et al. have shown that variations in maternal care in rats result in nongenomic behavioural transmission of individual differences in stress response across generations [II]. Maternal licking, grooming and nursing hehaviour (I,GN) is a major determinant of endocrine and behavioural stress responses in offspring. Adult offspring of high LGN mothers are less fearful and show smaller hypothalamic-pituitary-adrenal responses to stress. Genetic transmission might he supposed because female offspring of high-LGN mothers display high-LGN behaviour with their own pups. However, when female pups born to lowLGN mothers are cross-fostered, female pups reared by high-LGN foster mothers 
become high-LGN with their pups. Thus, we observe a maternal behaviour that is transmitted across generations by nongenomic means — if you will, by "culture".

What is the mechanism? Maternal care controls gene expression in brain regions regulating stress response. When pups exposed to high-LGN rearing become adult, they display increased hippocampal glucocorticoid receptor mRNA expression, higher central benzodiazepine receptor levels in the amgydala, and lower corticotropin releasing factor mRNA in the paraventricular nucleus of the hypothalamus. Social experience controls the way genes are expressed.

\section{Depression: the role of inheritance and experience}

In the case of depression, twin and family studies demonstrate unequivocal genetic roots for depression; yet there was a secular increase in the lifetime prevalence during the 20 th century [12]. That increase cannot be due to shifts in the gene pool; the time interval is far too short. The challenge is to identify the relevant environmental risk factors. Although depression is clearly familial, Genrge Brown and his colleagues [13] have demonstrated that experiences of humiliation and entrapment after a severe life-threatening event are major risk factors and that positive events involving hope are instrumental in recovery from depression [14]. In a recently reported randomized controlled trial, the same team of investigators found that "befriending" that is, providing to depressed women a female volunteer willing to meet and talk on a weekly basis, to go on excursions and to promote "fresh-start" experiences capable of creating new hope - improved outcome to a significant degree [15]. Human connections matter!

\section{Integrating neurobiology with behaviour}

Brain and mind are dependent on the surround, at the same time that they shape that surround and resist strains on integrity. It is not that mind and brain are evanescent; they have continuity. But they are far more malleable than we have understood, far more responsive to context, far more dependent on social input for maintaining integrity. Biomedical knowledge is essential for providing sound medical care but it is not sufficient; the doctor's dealings with the patient must also be informed by psychosocial understanding. Neither mindlessness nor brainlessness can be tolerated in medicine. The unique role of psychiatry will be its contribution to a new paradigm: brain/mindfulness, integrating neurobiology with behaviour in its social context. That is the intellectual challenge ahead.

\section{References}

1. Eisenberg L. Nature, niche and nunure: the role of social experience in transforming genotype into phenotype. Academio poychiatry, 1008, 22:213-22.
2. Eisenderg L. Does social medicine still matter in an era of molecular medicine? Joumal of urban health (Bulletin of the New York Academy of Medicine), 1909, 76:164-75. 
3. Eisenberg L. Mindlessness and brainlessness in psychiatry. British journal of psychiatry, 1986, 148:497-508.

4. Catalano SM, Shatz CJ. Activity-dependent target selection by thalamic axons. Science, 1998, 281:559-62.

5. Wiesel TN. The postnatal development of the visual cortex and the influence of environment (The 1981 Nobel Prize Lecture). Stockholm, Nobel Foundation, 1982.

6. Elbert $T$ et al. Increased cortical representation of the fingers of the left hand in string players. Science, 1995, 270:3057.

7. Sterr A et al. Changed perceptions in Braille readers. Nature, 1998, 391:1345.

8. Mogilner A, Grossman JAI, Ribary V. Somatosensory cortical plasticity in adult humans revealed by magnetoencephalography. Proceedings of the $\mathrm{Na}$ tional Academy of Science USA, 1993, $90: 3593-7$.

9. Eriksson PS, Perfilieva E, Bjork-Erisson $T$. Neurogenesis in the adult human hippocampus. Nature medicine. 1998. $4: 1313-7$.
10. Baxter Jr LR et al. Caudate glucose metabolic rate changes with both drug and behavior therapy for obsessivecompulsive disorder. Archives of general psychiatry, 1992, 49:681-9.

11. Francis $D$ et al. Non-genomic transmission across generations of maternal behavior and stress responses in the rat. Science, 1999, 285:1155-8.

12. Cross-National Collaborative Group. The changing rate of major depression: cross-national comparison. Journal of the American Medical Association, 1992, 268:3098-105.

13. Brown GW, Harris TO, Hepworth C. Loss, humiliation and entrapment among women developing depression: a patient and non-patient comparison. Peychological medicine, 1995, 25:7-21.

14. Brown GW. Life events and affective disorder: replications and limitations. Psychosomatic medicine, 1993, 55: 248-59.

15. Harris T, Brown GW, Robinson R, Befriending as an intervention for chronic depression among women in an inner city: randomized control trial. British journal of psychiatry, 1999, 174:219-32. 